\title{
A review of the renal system and diurnal variations of renal activity in livestock
}

Ewa Skotnicka ${ }^{1}$, Zbigniew Muszczyñski $^{2}$, Wioleta Dudzinska ${ }^{1}$, Maria Suska ${ }^{1}$

${ }^{1}$ Department of Physiology, Faculty of Life Sciences, University of Szczecin, Al. Piastow 40 B , 71-065 Szczecin, Poland

${ }^{2}$ Department of Physiological Chemistry, Faculty of Biotechnology and Animal Breeding, University of Agriculture, ul. Doktora Judyma 6, 71-466 Szczecin, Poland

\section{Corresponding author:}

Dr Ewa Skotnicka, Department of Physiology, Faculty of Life Sciences, University of Szczecin, Al. Piastow 40 B, $70-065$ Szczecin, Poland

Email: ewaskot@univ.szczecin.pl

Tel: $\quad+48914442754$

Fax: $\quad+48914442734$

Kidneys are the main organs regulating water-electrolyte homeostasis in the body. They are responsible for maintaining the total volume of water and its distribution in particular water spaces, for electrolyte composition of systemic fluids and also for maintaining acid-base balance. These functions are performed by the plasma filtration process in renal glomeruli and the processes of active absorption and secretion in renal tubules, all adjusted to an 'activity-rest' rhythm. These diurnal changes are influenced by a 24-hour cycle of activity of hormones engaged in the regulation of renal activity. Studies on spontaneous rhythms of renal activity have been carried out mainly on humans and laboratory animals, but few studies have been carried out on livestock animals. Moreover, those results cover only some aspects of renal physiology. This review gives an overview of current knowledge concerning renal function and diurnal variations of some renal activity parameters in livestock, providing greater understanding of general chronobiological processes in mammals. Detailed knowledge of these rhythms is useful for clinical, practical and pharmacological purposes, as well as studies on their physical performance.

Key words: Key words: diurnal variations, renal activity, effective renal blood/plasma flow, glomerular filtration rate, tubular resorption/secretion, electrolyte/water excretion

\section{Glossary:}

$\mathrm{ADH}$ - antidiuretic hormone

AVP - arginine-vasopressin, vasopressin

bw - body weight

$\mathrm{Ccr}$ - changes in glomerular filtration rate (GFR) based on

endogenic creatinine clearance

Cin - changes in glomerular filtration rate (GFR) based on inulin clearance

ERPF - Effective renal plasma flow $\left(\mathrm{ml} / \mathrm{min} / \mathrm{m}^{2}\right)$

EPBF - Effective renal blood flow $\left(\mathrm{ml} / \mathrm{min} / \mathrm{m}^{2}\right)$

FF - Filtration fraction (\%)

GFR - Glomerular filtration rate $\left(\mathrm{ml} / \mathrm{min} / \mathrm{m}^{2}\right)$

Posm - Plasma osmolality ( $\mathrm{mmol}_{\mathrm{kg} \mathrm{H}} \mathrm{O}$ )

Uosm - Urine osmolality $\left(\mathrm{mmol} / \mathrm{kg} \mathrm{H}_{2} \mathrm{O}\right)$

$\mathrm{P}$ - plasma level $(\mathrm{mmol} / \mathrm{l})$

C - clearance $\left(\mathrm{ml} / \mathrm{min} / \mathrm{m}^{2}\right.$ or $* \mathrm{ml} / \mathrm{min} / \mathrm{kg}$ bw)

$\mathrm{F}$ - filtered load $\left(\mathrm{mmol} / \mathrm{min} / \mathrm{m}^{2}\right)$

TR - tubular resorption (\%)

$\mathrm{U}^{*} \mathrm{~V}-$ excretion in urine $\left(\mu \mathrm{mol} / \mathrm{min} / \mathrm{m}^{2}\right.$ or ${ }^{*} \mu \mathrm{mol} / \mathrm{min} / \mathrm{kg}$ bw)

\section{Introduction}

Living matter and evolving organisms are influenced by the Earth's rotation and revolution around the sun with its periodicity of day/light and night/darkness, with periodic changes in the length of the daily light and dark span and with seasons and climatic changes. Therefore, a variety of biological variables oscillate within an organism including: behaviour, physiological functions; and, biochemical factors. If any event within a biological system recurs at approximately regular intervals, it is generally referred to as a biological rhythm. Biological rhythms affect a variety of activities, such as the sleep-wake cycle, migration behaviour (birds, fish), seasonal fattening, reproductive cycles etc. The predominant rhythms in nature are daily rhythms e.g., rest-activity, body temperature, synthesis and/or secretion of many hormones, heart and respiratory rate, blood pressure, glomerular filtration rate, renal plasma flow, electrolyte concentrations in urine etc. Studies on chronobiological aspects of physiological functions have been carried out mainly on humans and laboratory animals (Koopman et al., 1989; Refinetti and Menaker, 1992; Windle et al., 1992). 
Few studies have been carried out on livestock (Piccione $e t$ al., 2002, 2003a, 2003b, 2004, 2005).

\section{Biological rhythms and circadian clock}

Daily biological rhythms are endogenously controlled by self-contained circadian clocks, which are not merely passive responses to the daily alternation of light and darkness, as they persist even in a non-periodic environment (e.g., constant light). The word 'circadian' implies that under constant external conditions the rhythms free-run with a period of approximately, but not precisely, twenty-four hours. Recent evidence indicates that the length of the period is controlled by an endogenous circadian oscillator (clock, zeitgeber, pacemaker) (Aschoff, 1981; Edmunds, 1994; Ikonomov et al., 1998).

Animals appear to have central clocks that reside in discrete pacemaker tissues in the central nervous system, whose signals direct circadian output responses in peripheral tissue areas (Takahashi, 1995). Pacemakers are primary oscillators, genetically determined self-sustained oscillators without external time cues, which provide timing signals that synchronise a multitude of rhythms in the same frequency range. The suprachiasmatic nuclei (SCN), localised to a region of the hypothalamus, is an example of an anatomical locus of the mammalian circadian clock. This circadian oscillator can impose daily patterns on a wide array of physiological functions via retino-hypothalamic projection (Gillette and Reppert, 1987; Cassone and Stephan, 2002). Most physiological rhythms have both endogenous and exogenous influences (e.g., the renal system).

Diurnal rhythmicity of renal activity in animals, maintained under a synchronised light-dark cycle, is characterised by three parameters: (1) the mean value around which parameters oscillate, the 'phase' of the oscillation in relation to the light-dark cycle; (2) the peak, being referred to as the 'acrophase'; and, (3) the minimum value, referred to as the 'batyphase'.

\section{Diurnal variability of renal system}

Kidneys are the main organs regulating water-electrolyte homeostasis in the body. They are responsible for maintaining the total volume of water and its distribution in particular water spaces, for electrolyte composition of bodily fluids and also for maintaining acid-base balance. These functions are performed by plasma filtration in renal glomeruli and absorption and secretion in renal tubules (Belsano, 1991; Kokot, 1992).

Spontaneous rhythms of renal activity have been reported for many years (Branderberger et al., 1998; Koopman et

Table 1: Mean values (or range of values) of effective renal plasma flow (ERPF), effective renal blood flow (ERBF), glomerular filtration rate (GFR), filtration fraction (FF), diuresis, urine osmolality (Uosm) in some species of livestock. GFR $-\left(\mathrm{ml} / \mathrm{min} / \mathrm{m}^{2}\right)$ or ${ }^{*}(\mathrm{ml} / \mathrm{min} / \mathrm{kg}$ body weight $)$

\begin{tabular}{|c|c|c|c|c|c|c|c|c|}
\hline & $\begin{array}{l}\text { ERPF } \\
\left(\mathrm{ml} / \mathrm{min} / \mathrm{m}^{2}\right)\end{array}$ & $\begin{array}{l}\operatorname{ERBF}(\mathrm{ml} / \\
\left.\mathrm{min} / \mathrm{m}^{2}\right)\end{array}$ & $\begin{array}{l}\text { GFR } \\
\left(\mathrm{ml} / \mathrm{min} / \mathrm{m}^{2}\right) \\
\text { or } \\
*(\mathrm{ml} / \mathrm{min} / \mathrm{kg} \mathrm{bw})\end{array}$ & $\begin{array}{l}\mathrm{FF} \\
(\%)\end{array}$ & $\begin{array}{l}\text { Uosm } \\
(\mathrm{mmol} / \\
\left.\mathrm{kg} \mathrm{H}_{2} \mathrm{O}\right)\end{array}$ & $\begin{array}{l}\text { Numbers of } \\
\text { animals }\end{array}$ & $\begin{array}{l}\text { Age of } \\
\text { animals }\end{array}$ & References \\
\hline \multirow{2}{*}{ goats } & 490 & 650 & 55 & 10 & 1100 & 12 & & Vogel (1962) \\
\hline & & 650 & 51 & 10 & 1100 & 12 & & Ketz (1960) \\
\hline goat kids & & & $1.69-3.08 *$ & & & 8 & $\begin{array}{l}\text { 8-30 days } \\
\text { old }\end{array}$ & Drzezdzon et al. (2001) \\
\hline \multirow[t]{2}{*}{ sheep } & 490 & & 58 & & & 12 & & Vogel (1962) \\
\hline & & & $1.1-2.3 *$ & & & $\begin{array}{l}89 \text { female } \\
19 \text { male }\end{array}$ & & $\begin{array}{l}\text { Bickhardt and Dungelhoef } \\
\text { (1994) }\end{array}$ \\
\hline \multirow[t]{2}{*}{ cattle } & 472 & & 73 & & $>1100$ & 12 & & Ketz (1960) \\
\hline & & & 70 & & & & & $\begin{array}{l}\text { Boehnecke and Tiews } \\
\text { (1972) }\end{array}$ \\
\hline \multirow[t]{7}{*}{ calves } & & & $1.75-3.32 *$ & & & 10 & $\begin{array}{l}1-14 \text { days } \\
\text { old }\end{array}$ & Skrzypczak (2001) \\
\hline & $230-289$ & $359-455$ & $36.5-47.8$ & $14-19$ & & 10 female & $\begin{array}{l}\text { 1-7 days } \\
\text { old }\end{array}$ & Skrzypczak (1991) \\
\hline & & & & 20 & & & & Dalton (1968) \\
\hline & & & & $14-24$ & & 12 & & Ketz (1960) \\
\hline & 326 & & & & & & $\begin{array}{l}2-3 \text { days } \\
\text { old }\end{array}$ & Hartmann et al. (1987) \\
\hline & 379 & & & & & & $\begin{array}{l}4-20 \text { days } \\
\text { old }\end{array}$ & Hartmann et al. (1987) \\
\hline & 351 & & $2.31 *$ & & & 23 & $\begin{array}{l}1-6 \text { weeks } \\
\text { old }\end{array}$ & Wanner et al. (1981) \\
\hline pigs & & & & & $<1100$ & & & Vogel (1962) \\
\hline
\end{tabular}


al., 1989). The diurnal changes in the renal blood flow intensity, glomerular filtration and excretion with urine, are still a subject of intense study. These diurnal changes are influenced by a 24-hour cycle of activity of hormones engaged in the regulation of renal activity e.g., AVP (arginine-vasopressin), vasoactive peptides, the reninangiotensin-aldosterone complex and melatonin. The cycle involves synthesis, excretion and concentration of hormones in blood plasma, but most importantly the activity of effector target sites (George et al., 1975; Van Acker et al., 1993; Boemke et al., 1995; Skotnicka and Hlynczak, 2001; Skotnicka, 2003, 2004, 2005).

Melatonin, the neurohormone of the pineal gland, plays a role in the regulation of the function of many body systems and, likewise, circadian rhythms. Recent studies suggest a possible role of melatonin in the regulation of water and electrolyte metabolism and renal function, by influencing the RAA system activity (Kawashima et al., 1987; Song et al., 1993; Song et al., 1995), through synthesis and/or secretion of AVP (Richardson et al., 1992; Forsling et al., 1993; Juszczak et al., 1995; Forsling, 2000) and through direct influence on melatonin receptors in kidneys (Song et al., 1993; Viswaythan et al., 1993; Song et al. 1995; Song et al., 1997).

The vegetative nervous system, which shows a diurnal variation as well, also seems to play a certain role here. Many investigators have reported that renal activity indices, like sympathetic activity, increase significantly during the day and decrease during the night; parasympathetic activity does the opposite (Lapinski et al., 1993; Branderberger et al., 1994; Dabrowska and Lapinski, 1996). Studies on renal activity diurnal variation have been carried out mainly on humans (Bultasova et al., 1986; Aslanian et al., 1989; Koopman et al., 1989; Ballauf et al., 1991; Cugini et al., 1992) and laboratory animals (Luke et al., 1991; Aizman et al., 1994; Schnecko et al., 1995). Few studies have been carried out on livestock. Moreover, their results cover only some aspects of renal physiology (Skrzypczak et al., 1992a, 1992b; Muszczynski, 1995).

\section{Effective renal blood and plasma flow and glomerular filtration rate}

Values of the effective renal blood and plasma flow (ERBF, ERPF) and glomerular filtration rate (GFR) are indicators of glomerular activity. The values of both ERBF and ERPF are very different in livestock species and increase with kidney development. GFR value depends directly on the effective filtration pressure and the area and permeability of the active filtration membrane. (Ketz, 1960; Vogel, 1962; Boehncke and Tiews, 1972; Skrzypczak, 1991; Drzezdzon et al., 2001).

ERPF through kidneys in goats is about $490 \mathrm{ml} / \mathrm{min} / \mathrm{m}^{2}$ (Vogel, 1962). Similar values were observed in sheep by Vogel (1962) and in cattle $\left(472 \mathrm{ml} / \mathrm{min} / \mathrm{m}^{2}\right)$ by Ketz (1960). ERPF in calves in the postnatal period of life was 230-
$289 \mathrm{ml} / \mathrm{min} / \mathrm{m}^{2}$ (Skrzypczak 1991). Effective renal blood flow (ERBF) in goats, according to Ketz (1960) and Vogel (1962), is about $650 \mathrm{ml} / \mathrm{min} / \mathrm{m}^{2}$ and the filtration fraction (FF) volume is about $10 \%$. ERBF in calves in the postnatal period of life is $359-455 \mathrm{ml} / \mathrm{min} / \mathrm{m}^{2}$ and $\mathrm{FF}$ about $14-19 \%$ (Skrzypczak, 1991). According to Ketz (1960), the volume of GFR in goats (measured both by the volume of insulin clearance and endogenic creatinine) is $51 \mathrm{ml} / \mathrm{min} / \mathrm{m}^{2}$. Similar results were reported in sheep $\left(58 \mathrm{ml} / \mathrm{min} / \mathrm{m}^{2}\right)$ by Vogel (1962). GFR in adult cows is higher - about 70 $\mathrm{ml} / \mathrm{min} / \mathrm{m}^{2}$ (Boehncke and Tiews, 1972). GFR in goat kids on the first month after birth is low and ranges from 1.69 to $3.08 \mathrm{ml} / \mathrm{min} / \mathrm{kg}$ body weight (Drzezdzon et al., 2001). GFR in newborn calves is similar and ranges from 1.75 to $3.32 \mathrm{ml} / \mathrm{min} / \mathrm{kg}$ body weight (Skrzypczak and Drzezdzon, 2001). Some ERPF, ERBF and GFR values in livestock are shown in Table 1. ERBF, ERPF and GFR show the greatest variation during a 24-hour period. GFR value in livestock, measured by the volume of inulin clearance (Cin) as well as based on endogenic creatinine clearance (Ccr), shows the highest volume (acrophase) during the day and the lowest volume (batyphase) at night. GFR also increases with an animal's age and development (Vogel, 1962; Skrzypczak et al., 1992a; Muszczynski, 1995).

Muszczynski (1995) demonstrated the existence of GFR diurnal rhythms in goats, on the basis of insulin clearance. The filtration varied from 41.2 to $62.3 \mathrm{ml} / \mathrm{min} / \mathrm{m}^{2}$, with an acrophase at 13:40. The same author also examined changes in glomerular filtration using endogenic creatinine (Ccr) and proved that, despite the observed differences in the volume of both clearances, the courses of particular rhythm phases were similar. Similarly, Vogel (1962), observed four-week-old goats to have 'day-night' differences in glomerular filtration (Ccr at 08:00hr was $46.4 \mathrm{ml} / \mathrm{min} / \mathrm{m}^{2}$; Ccr at 20:00hr was $24.6 \mathrm{ml} / \mathrm{min} / \mathrm{m}^{2}$ ). Also Skrzypczak et al. (1992a) observed significant 'day-night' differences in GFR volume in four-week-old calves (Cin at 10:00 hr was 60.39 $\mathrm{ml} / \mathrm{min} / \mathrm{m}^{2}$, Cin at 22:00hr was $49.99 \mathrm{ml} / \mathrm{min} / \mathrm{m}^{2}$ ). Diurnal variations of GFR for some livestock animals have been shown in Table 2.

The GFR increases during the light phase of the photoperiod with an increase in blood pressure and a simultaneous increase in filtration pressure in renal glomeruli (ERBF/ERPF are in phase with the GFR rhythm) (Koopman, 1989). The circadian rhythm of GFR in livestock is most likely affected by autonomic nervous system activity and also by circadian fluctuations of the following systems: the hypothalamus-hypophysis axis; vasoactive peptides; and, the renin-angiotensinaldosterone complex, as studies on humans suggest (Koopman, 1989; Van Acker et al., 1993). Feeding time and diet (particularly the protein content in food) can modify renal activity, which results in hyperperfusion and then plasma hyperfiltration in renal glomeruli (Stoynev and Ikonomov, 1983; Luke et al., 1991; Skrzypczak et al., 1996). However, Muszczynski (1995), in his studies 
on goats, did not observe an influence of feeding time on GFR diurnal variation.

\section{Tubular resorption and secretion and electrolyte excretion with urine}

Kidneys of adult livestock can be very economical in sodium and chloride excretion. Tubular sodium resorption $\left(\mathrm{TR}_{\mathrm{Na}}\right)$ and chloride resorption $\left(\mathrm{TR}_{\mathrm{Cl}}\right)$ in goats, sheep and cattle renal duct tubules are above $93-100 \%$ of the filtered load (Ketz, 1960; Vogel, 1962). Tubular sodium and chloride resorption in calves and goat kids in the postnatal period are stable and similar to the levels in adult animals (Skrzypczak, 1991; Drzezdzon et al., 2001). Potassium resorption is significantly lower than sodium and chloride resorption and is between $24 \%$ and $54 \%$ of the filtered load in calves (Skrzypczak, 1991), 70.5\% in goats and $90 \%$ in sheep (Vogel, 1962). Values of tubular resorption (TR) and filtered load $(\mathrm{F})$ of sodium, potasssium and chloride ions in livestock are presented in Table 3.
The changes in electrolyte excretion with urine $\left(\mathrm{U}^{*} \mathrm{~V}\right)$ are due to the filtration in renal glomeruli and resorption in tubules. The volume of electrolyte excretion is different for various species of livestock and depends on their age and development. Electrolyte excretion varies greatly in the first week of the animal's life (Skrzypczak, 1991; Drzezdzon et al., 2001). Values of electrolyte excretion in urine $\left(\mathrm{U}^{*} \mathrm{~V}_{\mathrm{Na}}\right.$, $\mathrm{U} * \mathrm{~V}_{\mathrm{K}}, \mathrm{U} * \mathrm{~V}_{\mathrm{Cl}}$ ) have been shown in Table 3.

The diurnal rhythm of sodium, potassium and chloride filtered load (F) in goats (Muszczynski, 1995) have acrophases during the day, the changes in $\mathrm{F}_{\mathrm{Na}}$ and $\mathrm{F}_{\mathrm{K}}$ being parallel to those in GFR. Tubular resorption of sodium $\left(\mathrm{TR}_{\mathrm{Na}}\right)$ and potassium $\left(\mathrm{TR}_{\mathrm{K}}\right)$ also show a diurnal rhythm with an acrophase at night, ranging from $94.44 \%$ to $99.83 \%$ for sodium and from $75.94 \%$ to $82.92 \%$ for potassium. However, tubular resorption of chloride is rather stable, ranging from $97.21 \%$ to $98.92 \%$ compared to the filtered load, with the lowest values (batyphase) in the morning. In goats, diurnal rhythms of sodium, potassium and

Table 2: Mean values (or range of values) of diurnal variations of selected indicators of renal activity in some species of livestock. Acrophase is the peak value. Batyphase is the minimum value. GFR - $\left(\mathrm{ml} / \mathrm{min} / \mathrm{m}^{2}\right) ; \mathrm{C}_{\mathrm{Na}}, \mathrm{C}_{\mathrm{K}}, \mathrm{C}_{\mathrm{Cl}}, \mathrm{CH}_{2} \mathrm{O}\left(\mathrm{ml} / \mathrm{min} / \mathrm{m}^{2}\right) ; \mathrm{TR}_{\mathrm{Na}}, \mathrm{TR}_{\mathrm{K}}, \mathrm{TR}_{\mathrm{Cl}}(\%) ; \operatorname{diuresis}\left(\mathrm{ml} / \mathrm{min} / \mathrm{m}^{2}\right) ;$ and, Uosm $(\mathrm{mmol} / \mathrm{kg} \mathrm{H} \mathrm{O})$.

\begin{tabular}{|c|c|c|c|c|c|c|}
\hline & \multirow[t]{2}{*}{ Species } & \multicolumn{2}{|l|}{ Acrophase } & \multicolumn{2}{|l|}{ Batyphase } & \multirow[b]{2}{*}{$\begin{array}{l}\text { References } \\
\text { [n - numbers of animals] }\end{array}$} \\
\hline & & $\begin{array}{l}\text { clock time (hr) or } \\
\text { midnight period }\end{array}$ & Mean value & $\begin{array}{l}\text { clock time (hr) or } \\
\text { midnight period }\end{array}$ & Mean value & \\
\hline \multirow[t]{3}{*}{ GFR } & goats & $13: 40 \mathrm{hr}$ & $61.9-62.3$ & at night & $41.2-51.6$ & Muszczynski (1995); [n=12] \\
\hline & goat kids & $10: 00 \mathrm{hr}$ & 46.4 & at night & 24.6 & Vogel (1962); [n=12] \\
\hline & calves & In the day & 60.39 & at night & 49.99 & Skrzypczak et al. (1992a); [n=6] \\
\hline $\mathbf{P}_{\mathrm{Na}}, \mathbf{P}_{\mathrm{K}}, \mathbf{P}_{\mathrm{Cl}}$ & goats & \multicolumn{4}{|c|}{ constant } & Muszczynski (1995) \\
\hline$P_{\mathrm{Na}}$ & \multirow{3}{*}{ calves } & 20:00 hr & & & & \multirow{3}{*}{ Skotnicka et al. (1997); [n=10] } \\
\hline$P_{K}$ & & $08: 30 \mathrm{hr}$ & & & & \\
\hline $\mathbf{P}_{\mathrm{Cl}}$ & & constant & & & & \\
\hline $\mathrm{TR}_{\mathrm{Na}}$ & \multirow{3}{*}{ goats } & $22.00 \mathrm{hr}$ & 99.8 & $12.00 \mathrm{hr}$ & 94.44 & \multirow{3}{*}{ Muszczynski (1995) } \\
\hline $\mathrm{TR}_{\mathrm{K}}$ & & $03.00 \mathrm{hr}$ & 82.92 & $12.00 \mathrm{hr}$ & 75.94 & \\
\hline $\mathbf{T R}_{\mathrm{Cl}}$ & & constant & $97.21-98.92$ & & & \\
\hline $\mathrm{TR}_{\mathrm{Na}}$ & \multirow{3}{*}{ calves } & in the day & & at night & & \multirow{3}{*}{ Skrzypczak (1992b) } \\
\hline $\mathrm{TR}_{\mathrm{K}}$ & & at night & & in the day & & \\
\hline $\mathrm{TR}_{\mathrm{Cl}}$ & & in the day & & at night & & \\
\hline $\mathrm{C}_{\mathrm{Na}}$ & \multirow{4}{*}{ goats } & $12: 00 \mathrm{hr}$ & 0.08 & \multirow{4}{*}{$03.00 \mathrm{hr}$} & 0.35 & \multirow{4}{*}{ Muszczynski (1995) } \\
\hline $\mathrm{C}_{\mathrm{K}}$ & & 14:00 hr & 7.86 & & 14.4 & \\
\hline $\mathrm{C}_{\mathrm{Cl}}$ & & $17: 00 \mathrm{hr}$ & 0.65 & & 1.24 & \\
\hline $\mathrm{CH}_{2} \mathrm{O}$ & & $12: 00 \mathrm{hr}$ & & & & \\
\hline $\mathrm{C}_{\mathrm{Na}}$ & \multirow{3}{*}{ goat kids } & \multirow{3}{*}{ in the day } & 0.17 & \multirow{3}{*}{ in the evening } & 0.08 & \multirow{3}{*}{ Vogel (1962) } \\
\hline $\mathrm{C}_{\mathrm{K}}$ & & & 15.0 & & 11.0 & \\
\hline $\mathrm{C}_{\mathrm{Cl}}$ & & & 0.52 & & 0.33 & \\
\hline $\mathrm{F}_{\mathrm{Na}}, \mathrm{F}_{\mathrm{K}}, \mathrm{F}_{\mathrm{Cl}}$ & goats & $14.00 \mathrm{hr}$ & & & & Muszczynski (1995) \\
\hline$\left(U^{*} V\right)_{\mathrm{Na}}$ & \multirow{4}{*}{ goats } & $13.00 \mathrm{hr}$ & & \multirow{4}{*}{$03.00 \mathrm{hr}$} & & \multirow{4}{*}{ Muszczynski (1995) } \\
\hline$\left(\mathrm{U}^{*} \mathrm{~V}\right)_{\mathrm{K}}$ & & $14.00 \mathrm{hr}$ & & & & \\
\hline$\left(\mathrm{U}^{*} \mathrm{~V}\right)_{\mathrm{Cl}}$ & & $16.00 \mathrm{hr}$ & & & & \\
\hline$\left(\mathrm{U}^{*} \mathrm{~V}\right) \mathrm{H}_{2} \mathrm{O}$ & & $13.30 \mathrm{hr}$ & & & & \\
\hline$\left(\mathrm{U}^{*} \mathrm{~V}\right)_{\mathrm{K}}$ & calves & & & at night & & Skrzypczak (1992b) \\
\hline \multirow[t]{2}{*}{ Diuresis } & goats & in the day & 1.26 & at night & 0.39 & Muszczynski (1995) \\
\hline & goat kids & in the day & 1.32 & in the evening & 0.62 & Vogel (1962) \\
\hline \multirow[t]{2}{*}{ Uosm } & goats & at night & 1245.9 & in the day & 828.7 & Muszczynski (1995) \\
\hline & goat kids & at night & 367 & in the day & 215 & Vogel (1962) \\
\hline
\end{tabular}


chloride excretion in urine $\left(\mathrm{U}^{*} \mathrm{~V}\right)$ have acrophases during the day. The lowest renal elimination for these electrolytes (batyphase) is at night. The data are presented in Table 2. Renal activity of two-week-old calves (Skrzypczak et al. 1992b) shows higher sodium and chloride resorption during the day and lower at night. Trends of changes in the filtered load and excretion of sodium and chloride are parallel. Changes in the tubular resorption of potassium are the opposite - resorption is higher at night, which results in decreased potassium excretion with urine. Tubular resorption and secretion and electrolyte excretion with urine reach a maximum during the day and a minimum at night in other species of mammals, including dogs (Boemke et al., 1995), rats (Stoynev and Ikonomov, 1983; Luke et al., 1991) and humans (Bultasova et al., 1986; Aslanin et al., 1989; Koopman et al., 1989; Ballauf et al., 1991). Koopman et al. (1989) observed a positive correlation between sodium excretion and GFR rhythm acrophases in humans. According to that report, maximum values of potassium excretion occur earlier than the maximum glomerular filtration and are correlated with the potassium rhythm acrophase in plasma. The amount of excreted potassium depends mainly on the resorption processes and the tubular secretion in kidneys and, to a lesser extent, on the plasma filtration in renal glomeruli. Potassium excretion rhythm in adults is also very 'regular'. That is, it maintains regularity with the 24 hour cycle. Taking into consideration similarities between diurnal rhythms of livestock and other mammalian species, it seems that a similar mechanism may take place in livestock. The value of the renal plasma clearance coefficient for sodium, potassium and chloride in goats, sheep, cattle and horses is presented in Table 3.

The value of renal plasma clearance coefficient for electrolytes change over a 24 hour period. In goats (Muszczynski, 1995), diurnal rhythms for sodium renal plasma clearance range between 0.08 and $0.35 \mathrm{ml} / \mathrm{min} /$ $\mathrm{m}^{2}$; for potassium between 7.86 and $14.40 \mathrm{ml} / \mathrm{min} / \mathrm{m}^{2}$; and for chloride between 0.65 and $1.24 \mathrm{ml} / \mathrm{min} / \mathrm{m}^{2}$, with the acrophases in the day. The lowest values for the examined ions were observed at night. A similar trend was observed in goat kids: 'day-night' differences in renal plasma clearance of sodium, potassium and chloride ions were significantly lower in the evening than in the morning (Vogel, 1962) (Table 2). Many studies on various mammalian species (livestock, rats, humans) suggest that the circadian variation of plasma clearance of electrolytes is influenced by various factors. Apart from the duration of light and dark phases, the outer controller of the rhythm could be the time of meals during the day (Stoynev and Ikonomov, 1983), which modifies only the amplitudes of the circadian rhythms (Muratani et al., 1985). Undoubtedly all the aforementioned factors, especially sleep-activity phases, modify the rhythms of excretion of osmotically

Table 3: Mean values (or range of values) of tubular resorption and secretion and electrolyte (sodium, potassium and chloride) excretion in urine in some species of livestock. P - plasma level $(\mathrm{mmol} / \mathrm{l}) ; \mathrm{C}$ - clearance $\left(\mathrm{ml} / \mathrm{min} / \mathrm{m}^{2}\right) ; \mathrm{F}$ - filtered load $\left(\mathrm{mmol} / \mathrm{min} / \mathrm{m}^{2}\right) ; \mathrm{TR}$ - tubular resorption $(\%) ;$ and, $\mathrm{U}^{*} \mathrm{~V}-\mathrm{excretion} \mathrm{in} \mathrm{urine}\left(\mu \mathrm{mol} / \mathrm{min} / \mathrm{m}^{2}\right)$.

\begin{tabular}{|c|c|c|c|c|c|c|}
\hline & \multicolumn{6}{|l|}{ Sodium } \\
\hline & $P$ & C & $\mathrm{F}$ & TR & $\mathrm{U} * \mathrm{~V}$ & References [n - numbers of animals] \\
\hline \multirow[t]{2}{*}{ goats } & & 0,1 & & 99,9 & & Vogel (1962); [n=12] \\
\hline & $135-145$ & & & & & Muszczynski (1995); [n=12] \\
\hline goat kids & $143-149$ & & & $97.3-99.5$ & 1.19-5.68* & Drzezdzon et al. (2001); [n=8] \\
\hline sheep & & 0.76 & & 99.9 & & Vogel (1962) \\
\hline cattle & & 0.1 & & 99.9 & & Vogel (1962) \\
\hline \multirow[t]{2}{*}{ calves } & $120-135$ & $0.02-0.51$ & $4.7-6.0$ & & & Skrzypczak (1991); [n=10] \\
\hline & & & & $98.5-99.5$ & $0.22-4.3^{*}$ & Skrzypczak et al. (2001); [n=10] \\
\hline \multirow[t]{3}{*}{ horses } & & 0.1 & & & & Vogel (1962) \\
\hline & \multicolumn{6}{|c|}{ Potassium } \\
\hline & $\mathrm{P}$ & C & $\mathrm{F}$ & TR & $\mathrm{U} * \mathrm{~V}$ & \\
\hline \multirow[t]{2}{*}{ goats } & & 25 & & 70.5 & & Vogel (1962) \\
\hline & $4.5-5.4$ & & & & & Muszczynski (1995) \\
\hline sheep & & & & 90 & & Vogel (1962) \\
\hline cattle & & 80 & & & & Vogel (1962) \\
\hline \multirow[t]{3}{*}{ calves } & $3.4-4.9$ & $5.31-28.83$ & $0.15-0.21$ & $24-54$ & $26-134$ & Skrzypczak (1991) \\
\hline & \multicolumn{6}{|l|}{ Chloride } \\
\hline & $\mathrm{P}$ & C & $F$ & TR & $\mathrm{U} * \mathrm{~V}$ & \\
\hline \multirow[t]{2}{*}{ goats } & & 1.1 & & 99.28 & & Vogel (1962) \\
\hline & 93-103 & & & & & Muszczynski (1995) \\
\hline sheep & & 1.77 & & & & Vogel (1962) \\
\hline cattle & & 0.7 & & & & Vogel (1962) \\
\hline calves & $91-99$ & $0.16-2.38$ & $3.8-4.5$ & $93-100$ & $23-217$ & Skrzypczak (1991) \\
\hline horses & & 0.38 & & & & Vogel (1962) \\
\hline
\end{tabular}


active electrolytes in urine. Motor activity influences the circadian rhythms of both synthesis and release of certain hormones (e.g., vasopressin, vasoactive peptides, reninangiotensin-aldosterone and melatonin), which are direct cellular regulators of electrolyte absorption and secretion. It seems that the circadian rhythms of renal excretion of electrolytes are a consequence of diurnal changes in GFR and the volume of the filtered load. Resorption and secretion processes in the tubules may modify these changes, however not significantly (Koopman et al., 1989).

\section{Renal water excretion}

Electrolyte balance is closely connected with water balance, so any changes in electrolyte excretion are followed by changes in renal water economy. In mammals active during the day, the amount of excreted urine is lowest at night (in the rest phase) and the amplitude of changes lowers. During the day, diuresis increases (Muratani et al., 1985; Koopman et al., 1989; Skrzypczak et al., 1992a; Muszczynski, 1995).

In goats' excretion of water with urine, the osmotic clearance and free water clearance change diurnally, with an acrophase in the day and batyphase at night (Muszczynski 1995) (Table 2). In humans, the acrophase of water excretion with urine also takes place in the day (Muratani et al., 1985; Aslanin et al., 1989), with a certain similarity between circadian changes in diuresis and changes in electrolyte excretion.

Goat kidneys show a great ability in concentrating and diluting urine, the maximum urine osmolality being about $1100 \mathrm{mmol} / \mathrm{kg} \mathrm{H}_{2} \mathrm{O}$. This value is lower than those observed in cattle and sheep, but significantly higher than those in pigs (Ketz, 1960; Vogel, 1962) (Table 1). In four-week-old goat kids, there are certain differences in 'day-night' diuresis (with minimum values in the day and minimum values at evening) and 'day-night' urine osmolality (with minimum values in the day and minimum values at night) (Vogel, 1962) (Table 2). In adult goats, there are some changes in urine osmolality, showing a negative correlation with the changes in diuresis (Muszczynski, 1995) (Table 2). In calves, the diuresis diurnal rhythm is usually consistent with changes in glomerular filtration (Skrzypczak et al., 1992a), which is in accordance with the earlier data found in humans (Koopman et al., 1989).

It seems that GFR is not the only reason for diuresis circadian rhythms. Water excretion with urine could also be influenced by the level of the intake of liquids, changes in body posture and endocrinic factors (George et al., 1975; Asplund and Aberg, 1991; Van Acker et al., 1993; Boemke et al., 1995; Branderberger et al., 1998; Skotnicka and Hlynczak, 2001; Skotnicka 2003, 2005). Undoubtedly, an increase in diuresis during the active phase (day) and a decrease during rest (night) are consequences of a change in the concentration of antidiuretic hormones that reach kidneys at night, mainly vasopressin (and/or melatonin).

\section{Blood plasma electrolytes}

One of the consequences of renal filtration, resorption and secretion is the electrolyte concentration in blood and plasma osmolality. The blood plasma electrolyte concentration in adult livestock is relatively stable (Table 3). However, two-week-old calves show certain diurnal variation and the acrophases of sodium and potassium concentration in blood plasma are very different. At about 20:00hr and 08:30hr, respectively, the chloride concentration in plasma is, however, relatively stable (Skotnicka et al., 1997). Diurnal rhythm in potassium concentration, both in livestock and humans, has been reported by other authors (Kanabrocki et al., 1973; Bernardi et al., 1985; Koopman et al., 1989; Solomon et al., 1991; Branderberger et al., 1994, Muszczynski, 1995; Skotnicka, 2003).

Muszczynski (1995) and Skotnicka (2005), in goats, and Skotnicka et al. (1997), in calves, did not observe diurnal changes in plasma osmolality. However Skotnicka (2005), in a study on pregnant goats, observed significant plasma osmolality differences between maximum (in the evening) and minimum (in the morning). Many published studies of diurnal blood plasma electrolyte concentrations and plasma osmolality show the influence of other factors such as age, sex, physiological state and feeding (time, type of food, water availability) on the rhythmic periodicity.

\section{Conclusion}

The values of renal activity parameters (e.g., ERBF, ERPF, GFR, F, TR, U*V) are very different among livestock species and increase with animal age and kidney development. Changes in renal activity in livestock are mostly diurnal rhythms, with distinct periods, acrophases and different amplitudes.

Most renal activity indices have maximum values during the day and minimum values at night. Diurnal changes in renal activity (values of ERBF, ERPF, GFR, F, TR, U*V), with the relatively stable composition of blood plasma, seem to confirm the adaptational character of the rhythms. Through changes in GFR, diurnal changes in resorption and tubular secretion intensity, as well as changes in ultimate urine composition, kidneys make it possible for an organism to adapt to changing environments (also diurnal changes).

Detailed knowledge of renal diurnal rhythms is useful for clinical, practical and, especially, pharmacological purposes and studies on physical performance. Chronobiological studies are extremely important for veterinary medicine, not only for the application of better therapy and for more reliable interpretation of experimental results, but also for controlled and economical development of livestock productivity.

\section{References}

Aizman, R.J., Rabinovitz, L. and Mayer-Harnisch, C. (1994). Circadian 
rhythms and time course of adaptive sodium and potassium excretion in rats after nephrectomy. Am. Jo. Physiol. 266: 454-462.

Aschoff, J. (1981). Freerunning and entrained circadian rhythms. Handbook of Behavioral Neurobiology. Biological Rhythms 4: 81-93. Aslanian, N. L., Babajan, L. A., Erinian, G. Z. and Grigorian, D. Z. (1989). [Rhythms of electrolyte excretion in healthy humans] Lab Delo 55: 21-23 (in Russian).

Asplund, R. and Aberg, H. (1991). Diurnal variation in the levels of antidiuretic hormone in the elderly. Jo. Inter. Med. 229: 131-134. Ballauf, A., Rascher, W., Tolle, H. G., Wember, T. and Manz, F. (1991). Circadian rhythms of urine osmolality and renal excretion rates solutes influencing water metabolism in healthy children. Miner. Electrolyte Metab. 17: $377-382$

Belsano, F. (1991). The kidney and essential hypertension. Ann. Ital. Med. Int. 6: 93-106.

Bernardi, M., De Palma, R., Trevisani, F., Capani, F., Satanini, C., Barddini, M. and Gasbarrini, G. (1985). Serum potassium circadian rhythm. Relationship with aldosterone. Horm. Metabol. Res. 17: 695. Boehncke, E. and Tiews, J. (1972). [Glomerular filtration rate in calves and young bulls.] Z Tierphysiol Tierernahr Futtermittelkd 30: 259-267 (in German).

Bickhardt, K. and Dungelhoef, R. (1994). Clinical studies of kidney function in sheep. I. Methods and reference values of healthy animals. Dtsch. Tierarztl. Wochenschr. 101: 463-466.

Boemke, W., Palm, U., Mohnhaupt, R., Corea, M., Selliger, E. and Reinhardt, H. W. (1995). Influence of captopril on 24 hour balances and the diurnal patterns of urinary output, blood pressure, aldosterone and atrial natriuretic peptide in conscious dogs. Ren. Physiol. Biochem. 18: $35-$ 48.

Branderberger, G., Follenius, M., Giochot, B., Saint, J., Spiegel, K., Ehrhart, J. and Simon, C. (1994). Twenty four-hour profiles of plasma renin activity in relation to the sleep-wake cycle. J. Hypertens. 12: 277-283. Branderberger, G., Charloux, A., Groufier, C. and Otzenberger, H. (1998). Ultradian rhythms in hydromineral hormones. Horm. Res. 49: 131-135.

Bultasova, H., Veselkova, A., Brodan, V. and Pinsker, P. (1986). Circadian rhythms of urinary sodium, potassium and some agents influencing their excretion in young borderline hypertensives. Endocr. Exper. 20: 359-369.

Cassone, V.M. and Stephan, F.K. (2002). Central and peripheral regulation of feeding and nutrition by the mammalian circadian clock: Implications for nutrition during manned space flight. Nutrition 18: 814-819.

Cugini, P., Battisti, P., Di-Palma, L., Cavallini, M., Pozzilli, P., Scibilla, G., Letizia, G., Cassisa, A., Cioli, A.R. and Marino, B. (1992). Secondary aldosteronism documented by plasma renin and aldosterone circadian rhythm in subjects with kidney or heart transplantation. Ren. Fail. 14: 69-76.

Dalton, R.G. (1968). Renal function in neonatal calves: inulin, thiosulphate and para-aminohippuric acid clearance. Br. Vet. J. 124: 498-509.

Dabrowska, E. and Łapiñski, M. (1996). [Diurnal blood pressure variation in patients with hypertension]. Pol. Arch. Med. Wewn. 95: 147-152 (in Polish).

Drzezdzon, D., Dratwa, A. and Skrzypczak, W.F. (2001). Introductory research on the ability of kids' kidneys to save sodium. Folia Univ. Agric. Stetin., Zootech. 43: 107-110.

Edmunds, L.N. (1994). Cellular and molecular aspects of circadian oscillators: Models and mechanisms for biological timekeeping. In: Touitou, Y., Haus, E. (eds) Biological Rhythms in Clinical and Laboratory Medicine. Springer, New York, pp35-54.

Forsling, M.L., Stonghton, R.P., Zhou, Y., Kelestrimur, H. and Demaihe, C. (1993). The role of the pineal in the control of the daily patterns of neurophyphophysial hormone secretion. J. Pineal Res. 14: 45-51.

Forsling, M.L. (2000). Diurnal rhythms in neurohypophysial function. Exp. Physiol. 85: 179-186.

George, C. P., Messerli, F. H., Genest, J., Nowaczyñski, W., Boucher,

R., Kuchel, O. and Rojo-Orrega, M. (1975). Diurnal variation of plasma vasopressin in man. J. Clin. Endocrinol. Metab. 41: 332-338. Gillette, M.U. and Reppert, S.M. (1987). The hipothalamic suprachiasmatic nuclei, circadian patterns of vasopressin secretion and neuronal activity in vitro. Brain Res. Bull. 19: 135-139.

Hartmann, H., Schmietendorf, L., Devaux, S., Finsterbusch, L., Meyer, H. and Rudolph, C. (1987). [Relation between diarrheoa and kidney function in the calf]. Arch Exp Veterinarmed. 41:129-39 (in German).

Ikonomov, O.G., Stoynev, A.G. and Shisheva, A.C. (1998). Integrative coordination of circadian mammalian diversity: Neuronal networks and peripheral clocks. Progress in Neurobiology 54: 87-97.

Juszczak, M., Debeljuk, L., Bartke, A. and Stepniak, B. (1995). Melatonin inhibits oxytocin and vasopressin release from neurointermediate lobe of the hamster pituitary. Neuroendocrinology 6: 2453-2456.

Kanabrocki, E. L., Scheving, L. E., Halberg, F., Brewer, R. L. and Bird, T. J. (1973). Circadian variations of biochemical blood profile in man. Space Life Sci. 4: 258-265.

Kawashima, K., Miwa, Y., Fujimoto, K., Oohata, H.H., Nishino, H. and Koika, H. (1987). Antihypertensive action of melatonin in the spontaneously hypertensive rats. Clin. Exp. Hipertens. 9: 1121-1131. Ketz, H.A. (1960). [Kidney activity in domestic animals]. Arch. Exp. Vet. Med. 14: 411-419 (in German).

Kokot, F. (1992). [Renin-angiotensin systems. Pathophysiology, diagnostics and treatment.] Kardiol. Pol. 5: 291-300 (in Polish).

Koopman, M. G., Koomen, G. C., Krediet, R. T., De Moor, E. A., Hoek, F. J. and Arisz, L. (1989). Circadian rhythm of glomerular filtration rate in normal individuals. Clin. Sci. 77: 105-111.

Luke, D. R., Wasan, K. M. and Vadiei, K. (1991). Circadian variation in renal function of the obese rat. Renal Physiol. Biochem. 14: 71-80.

Lapinski, M., Lewandowski, J., Januszewicz, A., Kuch-Wocial, A., Symonides, B., Wocial, B. and Januszewicz, W. (1993). Hormonal profile of dipper and non-dipper patients with essential hypertension. J. Hypertens. 11 (Suppl. 5): 294-295.

Muratani, H., Kawasaki, T., Ueno, M., Kawazoe, N. and Fujishima, M. (1985). Circadian rhythms of urinary excretion of water and electrolytes in patiens receiving total parenteral nutrition. Life Sci. 37: 645-649.

Muszczyñski, Z. (1995). [A chronobiological aspect of kidney activity in goats]. 1st edn, Academy of Agriculture Press, Szczecin, Poland. (in Polish).

Piccione, G. and Caola, G. (2002). Biological rhythm in livestock. J. Vet. Sci. 3: 145-157.

Piccione, G., Caola, G. and Refinetti. R. (2003a). Daily and estrous rhythmicity of body temperature in domestic cattle. BMC Physiology 3:7 Piccione, G., Caola, G. and Refinetti. R. (2003b). Circadian rhythms of body temperature and liver function in fed and food-deprived goats. Comp. Biochem. Physiol. (A) 134: 563-572.

Piccione, G., Assensa, A., Grasso, F. and Caola, G. (2004). Daily rhythm of circulating fat soluble vitamin concentration (A, D, E and $\mathrm{K}$ ) in the horse. J. Circadian Rhythms 2:3.

Piccione, G., Grasso, F. and Giudice, E. (2005). Circadian rhythm in cardiovascular system of domestic animals. Res. Vet. Sci. 79: 155-160. Refinetti, R. and Menaker, M. (1992). Review: The circadian rhythm of body temperature. Physiol. Behav. 51: 613-637.

Richardson, B.A., Studier, E.H., Stallone, J.N. and Kennedy, C.M. (1992). Effects of melatonin on water metabolism and renal function in male Syrian hamsters (Mesocricetus auratus). J. Pineal Res. 13: 49-59.

Schnecko, A., Witte, K. and Lemmer, B. (1995). Effects of the angiotensin II receptor antagonist losartan on 24-hour blood pressure profiles of primary and secondary hypertensive rats. J. Cardiovasc. Pharmacol. 26: 214-221.

Skotnicka, E., Skrzypczak, W. F. and Ozgo, M. (1997). Circadian changes in electrolyte concentration in plasma and erythrocytes in two-week-old calves. Acta Vet. (Brno) 66: 141-146.

Skotnicka, E. and Hłyñczak, A.J. (2001). Melatonin and its possible role in regulation of water and electrolyte metabolism. Med. Wet. 5: 299-303. 
Skotnicka, E. (2003). Circadian variations of the plasma renin activity (PRA), aldosterone and electrolyte concentrations in blood plasma in pregnant and non-pregnant goats. Comp. Biochem. Physiol. (C) 134: $385-$ 395.

Skotnicka, E. (2004). Influence of pregnancy on diurnal changes of plasma melatonin, vasopressin and cortisol concentrations in goats. FEBS Journal 27 (Suppl.): 210.

Skotnicka, E. (2005). Diurnal changes of plasma arginine-vasopressin concentration in pregnant and non-pregnant goats (Capra hircus). Acta Vet. (Brno.) 74: 43-49.

Skrzypczak, W. F. (1991). [Water spaces volume and selected kidney activity indicators in calves in the first week of the postnatal period]. 1st edn. Academy of Agriculture Press, Szczecin, Poland: 136 (in Polish). Skrzypczak, W. F., Jankowiak, D., Muszczy ski, Z. and Janus, K. (1992a). [Diurnal variation in kidney activity in calves. I. Glomerular filtration]. 9th Conference PTNW, Olsztyn. Poland: 452 (in Polish).

Skrzypczak, W. F., Jankowiak, D., Muszczy ski, Z. and Janus, K. (1992b). [Diurnal variation in kidney activity in calves. II. Electrolyte excretion]. 9th Conference PTNW, Olsztyn. Poland: 453 (in Polish).

Skrzypczak, W. F., Ozgo, M., Janus, K., Skotnicka, E., Jankowiak, D. Muszczyñski, Z. and Suszycka, J. (1996). The influence of increased protein content in the diet on renal functions in calves. Acta Vet (Brno) 65: 115-121.

Skrzypczak, W. F and Drzezdzon D. (2001). Kidneys adaptation of kid and calf newborns to natremia regulation. EJPAU, Veterinary Medicine 4: 2.

Solomon, R., Weinberg, M. S. and Dubey, A. (1991). The diurnal rhythm of plasma potassium: relationship to diuretic therapy. J. Cardiovasc. Pharmacol. 17: 854-859.

Song, Y., Poon, A.M.S., Lee, P.P.N. and Pang, S.F. (1993). Putative melatonin receptors in the male guinea pig kidney. J. Pineal Res. 15: 153160.

Song, Y., Tam, P.C., Poon, A.M.S., Brown, G.M. and Pang, S.F. (1995). $2\left[{ }^{125} \mathrm{~J}\right]$ Jodomelatonin binding sites in the human kidney and the effect of guanosine5'-O-(3-triotriphosphate). Endocrinol. Metab. 80: 1560-1565. Song, Y., Chan, C.W., Brown, G.M., Pang, S.F. and Silverman, M. (1997). Studies on the renal action melatonin: evidence that the effects are mediated by $37 \mathrm{kDa}$ receptors of the Mella subtype localised primarily to the basolateral membrane of the proximal tubule. FASEB Journal 11: 93100 .

Stoynev, A. G. and Ikonomov, O. C. (1983). Effect of constant light and darkness on circadian rhythms in rats. I. Food and water intake, urine output and electrolyte excretion. Acta Physiol. Pharm. Bulg. 9: 58-64. Takahashi, J.S. (1995). Molecular neurobiology and genetics of circadian rhythms in mammals. Ann. Rev. Neurosci. 18: 531-553.

Wanner, M., Ziv, G., Nicolet, J., Noelpp, U.P. and Roesler, H. (1981) Experiments with the double isotope single-injection method for determining glomerular filtration rate and effective renal plasma flow in veal calves. Res. Vet. Sci. 30: 239-240.

Van Acker, B. A., Stroomer, M. K., Gosselink, M. A., Koomen, G. C., Koopman, M. G. and Arisz, L. (1993). Urinary protein excretion in normal individuals: diurnal changes, influence of orthostasis and relationship to the renin-angiotensin system. Contrib. Nephrol. 101: 143-150.

Viswythan, M., Laitinen, J.T. and Saavedra, J.M. (1993). Vascular melatonin receptors. Biol. Signals 2: 221-227.

Vogel, G. (1962). [Contribution to the knowledge on kidney physiology in some domestic mammals]. Zentl. Vet. Med. Beiheft. 3: 122-127 (in German). Windle, R. J., Forsling, M. L. and Guzek, J. W. (1992). Daily rhythms in the hormone content of the neurohypophysial system and release of oxytocin and vasopressin in the male rat: effect of constant light. J. Endocr. 133: 283-290. 